sciendo Порівняльна професійна педагогіка 8(4)/2018 Comparative Professional Pedagogy 8(4)/2018

DOI: $10.2478 /$ rpp-2018-0054

Senior Lecturer, ILONA ISAIEVA

Bohdan Khmelnytskyi National Academy of the State Border Guard Service of Ukraine Address: 46 Shevchenko St, Khmelnytskyi, 29000, Ukraine E-mail: isaeva_ilona@i.ua

\title{
POLICE TRAINING IN THE SYSTEM OF PROFESSIONAL TRAINING FOR FEDERAL POLICE FORCE IN GERMANY
}

\begin{abstract}
The article is devoted to the analysis of the peculiarities of organizing and conducting trainings in the system of professional training of personnel of the Federal Police of Germany (BPOL). The main focus is on the organization of training on the use of weapons, coercive means, situational training. It has been found out that during the exercises of firing proficiency not only the skills of marksmanship are worked out, but also various complex situational trainings are carried out, which reflect the situations of daily activities of the police and require them to take appropriate action (the correct contention resolution in terms of tactics of action and the lawfulness and decision making on the use or non-use of weapons). As a result of the use of general scientific methods for the analysis, synthesis and generalization of information of directive / documents, orders, scientific and didactic sources as well as studying and generalizing the pedagogical experience of organizing trainings for BPOL personnel, it was found that in the development of situational trainings and training on the use of weapons, coercive means and own security, the trainers of BPOL were guided by both traditional "linear" and "nonlinear" pedagogical principles for organization of training exercises. On the basis of the generalization of the research results, it has been established that the situations that are developed for such trainings are constantly updated and correspond to the realities of time. At the heart of all scenarios, there are nine standard police cases: police communication, personal identification, detention, search of persons, transportation of detainees, vehicle control, first medical aid, collection of materials for identification and its entry into the database, search of premises and belongings. While assessing the actions of a policeman in solving a situation, the trainers take into account: communication skills (both with the partner and with the "opponent"), tactics of action, compliance with the requirements of self-defence, the correct use of coercive means, the lawfulness of all measures taken, the provision of first medical care, achievement of a goal (solution of a situation).

Keywords: police training, situational training, professional training, Federal Police of Germany.

\section{INTRODUCTION}

The Federal Police of Germany (BPOL) established in 1951 as a Federal Border Guard has undergone a complex and long-term development from an agency with a military structure to a federal police force and has extensive experience in training highly skilled personnel. These are the BPOL representatives who are involved in foreign police missions,
\end{abstract}


are consultants on issues of visas and travel documents, the immigration policy of embassies of the Federal Republic of Germany in other countries

Experts, trainers and instructors from the training centres and the BPOL Academy repeatedly conducted classes and trainings of various directions with the personnel of the State Border Guard Service of Ukraine (SBGS), in particular, on the examination of travel documents, detection of counterfeits, identification of persons, methods of application of certain technical means, service dogsin the border protection, and representatives of the Bohdan Khmelnytskyi National Academy of SBGS of Ukraine visited educational establishments of the BPOL in order to get acquainted with various aspects of personnel training in course of implementation of the cooperation programs between the BPOL and the SBGS. This testifies to the fact that the SBGS responsible executives are interested in the experience and advanced technology of personnel training in the BPOL.

\section{THE AIM OF THE STUDY}

The purpose of our research is to analyse the peculiarities of organization and conduct of trainings in the system of professional training of the personnel of the BPOL in order to further substantiate the possibilities of using advanced ideas in the training of SBGS personnel.

\section{THEORETICAL FRAMEWORK AND RESEARCH METHODS}

Many well-known national scholars have made a significant contribution to updating the content, forms and optimization of professional training of law enforcement agencies in Ukraine, including the use of efficient and reliable training technologies: V. I. Barko, V. O. Lefterov, V. S. Medvediev, L. I. Moroz, H. V. Popova， S. M. Synov, A. V. Timchenko, S. I. Yakovenko and others.

The scientific and methodological researches of German and European experts in the field of professional police training: D. Bogatinov, L. Colin, S. Caljouw, G. Faber, S. Geerts, S. Jansen, S. Körner, P. Lameski, A. Landman, M. Leijsen, A. Nieuwenhuys, R. Oudejans, P. Renden, G. Savelsberg, B. Schmeits, G. Savelsbergh, M. Staller, A. Visser, B. Zaiserand others make up the theoretical and methodological basis of this study.

In the research, we used general scientific methods - analysis, synthesis and generalization - to study the directive documents regulating the organization and procedure for conducting police trainings in the BPOL, the scientific works of national and foreign, in particular German, scientists on the problem under investigation; empirical methods observation, survey, study and generalization of pedagogical experience accumulated by teachers and trainers of educational centres and the Academy of BPOL.

\section{RESULTS}

For a long time, the SBGS developed as a special law enforcement agency, but in its system of professional training, the emphasis was not placed on preparing personnel for activities in stressful situations, practicing the methods of personal weapons handling and using physical force until they become second nature. With the change in the situation at the state border of Ukraine in 2014, the approaches to border guarding and, accordingly, training of SBGS personnel were changed. More and more attention is paid to improving the skills of physical training, accurate fire, solving complex situational tasks, and conducting various types of trainingsin the educational process.

The English term "training" includes many meanings: education, upbringing, preparation, practice. This is due to the fact that from the 19th century, the training technology developed in many areas of science and practice - in psychiatry, in various fields of psychology as well as in pedagogy, in particular, in professionalpedagogy. 
The foreign practice of training specialists differs by the wide application of trainings. In particular, the system of compulsory communicative, anti-stress and other training courses to be taken by the police have been established in the police force of the USA, Germany, and United Kingdom. 80-90 \% of the study time is allocated for the practical training of theoretical knowledge obtained by the employees through business and role games, trainings, exercising scenarios of specific service situations and tasks, group discussions, etc.(Moroz, 2005).

The program for Police training in the BPOL (Konzeption: Polizeitraining in der Bundespolizei) includes: "Polizeisport" - physical training, "Schießaus- und fortbildung" training in firing proficiency, "Einsatztraining" - a complex of trainings on personal safety, the use of coercive means (handcuffs, batons, pepper spray) and "Situationstraining" situational trainings.

The main requirement for conducting the Police Training Program in the BPOL is "the organization of a training system based on the Real-Action-Marker in the units, the Academy and training centres of the BPOL, which should simulate as much as possible the real situations of service activities of policemen, including the use of fire arms".

Within the framework of the BPOL personnel training, approximately 600 academic hours from a total training load of 4,428 hours are given for conducting police trainings of the lower grade personnel during the period of 2.5 years (Ausbildungsplan für den Vorbereitungsdienst für den mittleren Polizeivollzugsdienst, 2014).

At the BPOL Academy, which provides training for the middle grade police personnel, 292 hours are allocated for the police trainings within 3 years of study, of which 265 hours - actual exercises/trainings and 27 hours - examinations (Diplomstudiengang (Diplomverwaltungswirt) (Modulhandbuch, 2010).

In the system of personnel training, the BPOL police training is scheduled for 84 hours per year, where there are 46.5 hours of situational trainings, 30 hours of physical trainings, and 7.5 hours of trainings in firing proficiency. Trainings are conducted to prepare policemen for performing their service duties and hitting qualifying standards: solving the standard police situation (once a year), sprint and endurance run, fulfilling qualifying standards in firing service pistols (every three months) and assault rifles (every six months). The results of examinations for qualifying standards are recorded in the personal files of policemen.

The aim of the weapons training in the Federal Police of Germany is to refine the skills of confident handling of service weapons. The theoretical and practical components of fire proficiency training are closely interrelated and contain legal and tactical issues as well as physical, psychological and ethical aspects of weapons engagement.

The system of weapons training in the Federal Police involves: studying the materiel equipment, mechanisms of small arms and the processes taking place during the shooting, types of ammunition and their actions; practicing the basic skills of weapons handling until they become second nature (positions of arms and fingers, muzzle control, identification of targets); practicing the movements in handling of weapons in compliance with the standards of personal security (fully equipped with all specified means of influence); continuous improvement of shooting skills; fixing and regularly checking the skills of confident weapon handling and shooting accuracy, including the conditions of physical load; gaining competence in the use of weapons depending on the situation. 
sciendo Порівняльна професійна педагогіка 8(4)/2018 Comparative Professional Pedagogy 8(4)/2018

In accordance with the "Order on Shooting Practice in the Framework of Training and Career Development of Policemen" 211 (PDV 211, 2005), the fire proficiency training involves two phases:

- Phase I (levels of training 1-3): development and improvement of skills of basic weapons manipulation, practicing basic movements in the use of weaponsuntil they become second nature, training of accurate fire during standard exercises and simulation exercises with situations close to service ones);

- Phase II (Level 4): in real life service situations, a policeman is required to take a timely decision on engagement of small arms, carry out any activities, timely assess their expediency, know legal and psychological aspects, take into account and observe the requirements for providing personal security. In this regard, when conducting trainings and training courses, trainers are not limited only to working out the skills of accurate fire. At the second stage, personnel are offered a variety of complex situational trainings that reflect the situations of daily activities of policemen and require them to take appropriate actions (tactically and legally correct resolving the conflict situation and making a decision on the use or non-use of weapons).

Situational training is aimed at the complex practicing of all elements of the previous training and best reflects the readiness of the policemen to perform official duties. Situations being developed for such trainings are constantly updated and correspond to the realities of time. At the heart of all scenarios, there are nine standard police situations: police communication, identification, detention, search of persons, transportation of detainees, vehicle control, first aid, collection of materials for identification and adding to a database, search of premises and belongings.

As shown by the analysis of scientific and didactic sources dealing with the issues of organizing and conducting situational trainings and trainings on the use of coercive meanswith police personnel, there are two main approaches to the organization of such trainings: the traditional one is "linear" and "nonlinear". Even so far, a model of so-called traditional reproductive learning is used. Its essence is the "linear" sequence of exercises: 1) demonstration of elements to be practiced, 2) multiple repetitions of movements shown by a teacher / trainer (Chow et. al., 2016; Staller, Zaiser, \& Körner, 2017). In this approach, the movements shown by a trainer are considered to be optimal and those who take part in the training are required to repeat the movements accurately which are then studied in isolation, "out of context" (Hooper, Butler \& Storey, 2009; Moy et al., 2015; Körner, Staller, 2018).Critics of the traditional approach point out its disadvantages:

- it does not account for individual characteristics of trainees (Chow et. al., 2016);

- it does not meet the principle of training a creative policeman capable of thinking and solving a service situation independently (Staller, \& Zaiser, 2015);

- such "context-free" trainings do not take into account the fact that in a real service situation, a policeman can be influenced by various external stimuli (Staller, Zaiser, \& Körner, 2017).

A new "non-linear" approach to conducting trainings with police officers on the use of weapons and personal safety is based on the paradigm of "ecologikal dynamics" (Araujo, Davis, \& Hristovski, 2006). The main condition of such an approach is the organization of such conditions for performing exercises, which would simulate the conditions as closely as possible for the use of trained elements in real service activities (Staller, 2015). This method is a real challenge for trainers, because when it is used, the 
sciendo Порівняльна професійна педагогіка 8(4)/2018 Comparative Professional Pedagogy 8(4)/2018

trainer should organize separate interconnected stages of training step-by-step in such a way that they are functionally varied and the individual characteristics of the trainees are considered. Another important task for the trainer is a thorough consideration of the conditions/tasks of exercises, since they should simulate the conditions of the actual service situation as closely as possible and take into account possible external stimuli (Staller, Zaiser, \& Körner, 2017, p. 16).

While assessing the actions of a policeman on solving a given situation, the trainers consider: communication (both with the partner and with the "opponent"), tactics of actions, compliance with the requirements of self-defence, the correct use of coercive means, the lawfulness of all measures taken, the provision of first medical aid, achievement of the goal (solution of the situation).

Plans for conducting trainings are made by heads of units in accordance with the general plan approved by the Presidium of the Federal Police and taking into account the results of the service activities of its own unit and other units of the Federal Police.

\section{CONCLUSIONS}

Our study leads to the following conclusions:

1) in the system of professional training of the personnel of the BPOL, the stress is laid upon the conduct of police trainings, which include physical training and fire proficiency training, a complex of trainings on personal safety, the use of coercive means (handcuffs, batons, pepper spray) and situational trainings;

2) while conducting fire proficiency trainings, not only are the skills of accurate fire, but also various complex situational trainings that reflect the situations of everyday activities of the police and require them to take appropriate actions (tactically and legally correct resolutions of conflict situations and decisions on use or non-use of weapons);

3 ) during the development of situational trainings and training on the use of weapons, coercive means and personal safety in the BPOL, the trainers are guided by both traditional "linear" and "nonlinear" pedagogical principles of organization of training exercises.

Further directions of research may be in a more detailed study of the theoretical principles of nonlinear pedagogy in the organization of situational trainings and training on the use of coercive means and personal safety as well as in familiarizing with the practical experience of training and conducting such trainings by trainers in the BPOL in order to substantiate the use of advanced technologies in the professional training of law enforcement officers of Ukraine and the SBGS personnel in particular.

\section{REFERENCES}

1. Araujo, D., Davids, K., \& Hristovski, R. (2006). The ecological dynamics of decision making in sport. Psychology of Sport and Exercise, 7 (6), 653-676.

2. Ausbildungsplan für den Vorbereitungsdienst für den mittleren Polizeivollzugsdienst in der Bundespolizei. BMI/BPOL: BI3-653 101/3. (2014).

3. Chow, J. Y., Davids, K., Button, C., \& Renshaw, I. (2016). Nonlinear pedagogy in skill acquisition. New York, NY: Routledge.

4. Diplomstudiengang (Diplomverwaltungswirt). Modulhandbuch/Modulares Curriculum. Lübeck: FHB. (2010).

5. Hopper, T., Butler, J., \& Storey, B. (Eds.). (2009). TGfU... Simply good pedagogy: understanding a complex challenge. Ottawa, ON: PHE-Canada. 
sciendo Порівняльна професійна педагогіка 8(4)/2018 Comparative Professional Pedagogy 8(4)/2018

6. Konzeption: PolizeitraininginderBundespolizei. ErlassBMI: BI3-653 507/9. (2007).

7. Körner, S., \& Staller, M. (2017). Pädagogik und Polizei!?: Forschung zur Professionalisierung polizeilichen Einsatztrainings.

8. Körner, S., \& Staller, M.(2018). System oder Pädagogik?: Auf dem Weg zu einer nichtlinearen Pädagogik der Selbstverteidigung im polizeilichen und zivilen Kontext. Polizei \& Wissenschaft, 1, 13-25.

9. Masterstudiengang: Öffentliche Verwaltung. Polizeimanagement (Publik Administration - Police Management). Modulhandbuch. (2014). Münster: Deutsche Hochschule der Polizei.

10. Moroz, L. (2005). Teoretychni zasady ta orhanizaciia psykholohichnoho treninhu $v$ orhanakh vnutrishnikh sprav. Kyiv.

11. Moy, B., Renshaw, I. \& Davids, K. (2015). The impact of nonlinear pedagogy on physical education teacher education students' intrinsic motivation. Physical Education and Sport Pedagogy, 21 (5), 517-538.

12. Nieuwenhuys, A., Savelsbergh, G. J. P., \& Oudejans, R. R. D. (2011). Shoot or don't shoot? Why police officers are more inclined to shoot when they are anxious. Emotion. Retrieved from http://doi.org/10.1037/a0025699.

13. Oudejans, R. R. D. (2008). Reality-based practice under pressure improves handgun shooting performance of police officers. Ergonomics, 51 (3), 261-273.

14. Polizeidienstvorschrift 211. (n.a.). Retrieved from http://www.ndsvoris.de/jportal/?quelle $=\quad$ jlink \&psml=bsvorisprod.psml\&feed=bsvoris-vv\&docid=VVNDVVND000035072

15. Renden, P. G., Savelsbergh, G. J. P., \& Oudejans, R. R. D. (2016). Effects of reflex-based self-defence training on police performance in simulated high-pressure arrest situations. Retrieved from http://doi.org/10.1080/00140139.2016.1205222.

16. Staller, M. (2015). Entscheiden und Handeln: Didaktische Überlegungen im polizeilichen Einsatztraining anhand eines Reglermodells für motorische und kognitive Anforderungen. Polizei \& Wissenschaft, 2, 24-36.

17. Staller, M. S., \& Zaiser, B. (2015). Developing problem solvers: new perspectives on pedagogical practices in police use of force training. The Journal of Law Enforcement, 4 (3), 1-15.

18. Staller, M., Zaiser, B., \& Körner S. (2017). Unverletzt besser werden: Repräsentative Simulationen im Polizeilichen Einsatztraining. Polizei Wissenschaft, 3, 13-27. 